\title{
ТРИВАЛІСТЬ ЖИТТЯ КОРІВ МОЛОЧНОї ХУДОБИ ЗАЛЕЖНО ВІД ОЦІНКИ ЛІНІЙНИХ ОЗНАК ВИМЕНІ
}

\author{
Хмельничий Леонтій Михайлович \\ доктор сільськогосподарських наук, професор \\ Сумський національний аграрний університет \\ ORCID: 0000-0001-5175-1291 \\ E-mail: khmelnychy@ukr.net
}

Карпенко Богдан Миколайович аспірант, спеціальність 204-ТВППТ Сумський національний аграрний університет ORCID: 0000-0002-9942-5863 E-mail: karpenkobogdan95@gmail.com

Наведено результати досліджень з вивчення залежності тривалості життя корів української чорно-рябої молочної (УЧРМ) та голштинської (Г) порід від рівня оцінки лінійних ознак, які характеризують морфологічні якості вимені у загальній системі лінійної класифікації екстер'єрного типу. Експерименти проведено у стаді господарства ПП "Буринське" Підліснівського відділення Сумського району. За результатами лінійної класиффікації описових ознак екстер'єрного типу, які характеризують морфологічні якості вимені корів-первісток піддослідних порід стада: прикріпленням передніх часток вимені, висотою прикріплення задніх часток, центральною зв'язкою, глибиною вимені, розташуванням та довжиною передніх дійок, встановлено певну співвідносну мінливість між рівнем оцінки цих ознак та тривалістю життя тварин. Високодостовірна різниия між коровами, оціненими за ознаку прикріплення передніх часток вимені в один та дев'ять балів, досить значна і становила 841 (УЧРМ; $P<0,001)$ та 810 ( $\Gamma$; $P<0,001)$ днів. Міжпородне порівняння тривалості життя корів, залежно від оцінки, свідчить на користь корів голштинської породи з мінливістю у межах 43-159 днів за недостовірної різниці. Різниця між найнижчою та найвищою оцінками за ознаку висоти заднього прикріплення вимені у корів піддослідних порід становила 740 (УЧРМ; P<0,001) та 810 (Г; P<0,001) днів Тварини з оцінкою за розвиток центральної зв'язки вимені нижчою за 1-3 бали живуть, відповідно до оцінюваних порід, від 2089 до 2401 (УЧРМ) та від 2154 до 2468 (Г) днів. Корови з оцінкою дев'ять балів обох порід відрізняються найвищою тривалістю життя - 2663 дні (УЧРМ), поступаючись коровам з самою низькою оцінкою на 754 дні $(P<0,001)$ та 2803 дні (Г) з достовірним перевищенням на 649 днів $(P<0,001)$. Різниця між середньою тривалістю життя корів з оцінкою дев'ять балів та оцінкою в один бал за глибину вимені становить у корів української чорно-рябої молочної породи 739 днів $(P<0,001)$, у корів голштинської - 832 дні $(P<0,001)$. Тривалість життя корів обох порід у стаді залежно від оцінки за розташування передніх дійок характеризується незначною криволінійною мінливістю. Тобто, найдовше використовуються у стаді корови обох порід з середньою оцінкою 7 балів. Надалі спостерігаються відхилення з недостовірною різницею у бік зменшення тривалості життя 3 оцінками 8-9 та 6-5 балів з перевагою корів голштинської породи. Істотне зниження показника тривалості життя у корів розпочинається з оцінками за цю ознаку від чотирьох до одного балу. Оцінка співвідносної мінливості довжини передніх дійок з тривалістю життя корів підконтрольних порід свідчить про те, що довше функціональне життя було у корів з середньою оцінкою п'ять балів, що дорівнює їхній довжині на рівні 5 см.

Ключові слова: українська чорно-ряба молочна порода, голштинська, лінійні ознаки типу, тривалість життя DOI: https://doi.org/10.32845/bsnau.Ivst.2021.2.3

Створені в Україні спеціалізовані молочні породи в сучасних умовах раціональної годівлі та безприв'язного утримання з доїнням у залі стають дедалі конкурентоспроможними на ринку виробництва молока. Інтродуковані тварини голштинської породи та створені вітчизняні, за рахунок використання поглинального схрещування, підтверджують це своїми високими результатами молочної продуктивності окремих господарств. Так, за даними держплемреєстру 2019 року [2] станом на 01.01.2020 р. надій корів голштинської породи стада ФГ "Перлина Турії", Волинської області, становив у середньому 12356 кг, а корів-первісток - 10910 кг, ПАТ "Агро-Союз", Дніпровської, відповідно - 10783 та 9601 кг, ТДВ "Терезине", Київської - 12142 та 11572 кг, СТОВ "Промінь", Миколаївської - 10843 та 9915 кг, ТОВ "Молоко вітчизни", Сумської - 10008 та 10230 кг, ФГ "Маїсс", Хмельницької - 10474 та 9954 кг, СТОВ "Агроко", Черкаської 10153 та 8800 кг та ПСП "Авангард", Чернігівської області 10173 та 8360 кг. Десятитисячний рубіж подолали також

господарства з розведення української чорно-рябої молочної породи. До них відносяться ТОВ "Прогрес", з надоєм по стаду та у віці першої лактації, відповідно - 10276 та 9985 кг та ФГ "Перлина Турії", Волинської області - 10920 та 9670 кг, СТОВ "Україна", Тернопільської - 11662 та 11230 кг, ТОВ АФ "Пісчанська", Харківської - 11213 та 10200 кг. Існує значна кількість господарств з продуктивністю 8-9 тисяч кг молока.

Нарощування спадковості голштинської породи беззаперечно призводить до збільшення молочної продуктивності, проте висококровні корови стають більш вибагливими до умов годівлі та утримання. Крім того, висока механізація технологічних процесів та зростання спадковості голштина за свідченнями багатьох досліджень [3, 18, 20, 25, 35, 40, 41, 52] впливають на зниження тривалості продуктивного використання та життя корів. Тому в сучасних умовах інтенсивних технологій виробництва молока показники довголіття корів молочних порід займають важливу ланку в економіч- 
ному ланцюзі розвитку галузі скотарства, оскільки від них істотним чином залежить рентабельність його ведення [7, 12]. Завдяки високій економічній вагомості, довговічність була зареєстрована національними молочними асоціаціями, як селекційна ознака $[13,51]$.

Подальша перспектива молочних господарств України неможлива без нарощування генетичного потенціалу продуктивності маточного поголів'я за рахунок використання сучасних методів селекції, одним із яких $€$ використання голштинських плідників зарубіжного походження. У цьому аспекті продуктивне довголіття молочних корів стає одним із головних критеріїв ефективності ведення молочного скотарства.

За свідченнями групи науковців, довголіття корів необхідно розглядати як складну і цілісну ознаку, яка детермінується низкою спадкових та паратипових чинників $[4,5,10$, 14, 17, 24, 27, 37, 38]. Оскільки селекціонерів цікавлять ознаки, які успадковуються, вирішення проблеми довголіття за рахунок спадкових чинників ускладняється якраз через низьку успадковуваність ознак, що його характеризують, особливо стосовно до тривалості життя. Світові дослідження підтверджують дану властивість. За даними авторів [47] ступінь мінливості успадковуваності тривалості життя становила 0,01-0,36 залежно від породи і методу дослідження. Авторами інших досліджень повідомляється, що успадковуваність тривалості життя корів голштинської породи варіювала від 0,05 до 0,07 [49], коефіцієнти успадковуваності у тварин симентальської породи Чехії перебували у межах від 0,04 до 0,05 [57], а голштинської - від 0,03 до 0,05 [58].

Проблема продуктивного довголіття молочної худоби у світі існує давно, тому селекціонери активно ведуть пошук методів для її вирішення. Одним із засобів, який дозволяє вирішувати проблему тривалості життя, є добір та підбір тварин за ознаками екстер'єрного типу, оскільки мотивація цього заходу ґрунтується на існуванні співвідносної мінливості між статями екстер'єру та показниками тривалості використання корів [8, 26, 34, 43, 48, 49, 56, 57], у тому числі й між ознаками вимені та довголіття [29, 31, 32, 33, 34, 35].

При визначенні зв'язку між оцінкою лінійних ознак вимені та тривалістю життя корів української чорно-рябої молочної породи встановлено, що корови з вищими оцінками за стан розвитку морфологічних ознак вимені - міцності прикріплення передніх часток (8 балів), висоти прикріплення задніх часток (8 балів), вираженості центральної зв'язки (9 балів) та глибини вимені (9 балів), мають істотну перевагу за тривалістю життя, перевищуючи тварин з самою низькою оцінкою на 762-970 днів. За оцінкою лінійної статі - розміщення передніх дійок, у стаді господарства найдовше використовувалися корови з оцінкою п'ять балів (2337 днів) [32].

За лінійною оцінкою джерсейських корів встановлено значні помірні та сильні позитивні генетичні кореляції між більшістю ознак вимені та функціональним життям корів стада (від 0,23 до 0,63) [44]. Автори [45] за дослідженнями мексиканських голштинів пропонують включити п'ять лінійних ознак (ширина грудей, довжина дійок, центральна зв'язка, текстура та глибина вимені), які позитивно корелювали з тривалістю продуктивного життя, у якості непрямих предикторів довголіття.

Автори [50] переконані, що непрямий генетичний добір за ознаками глибини вимені, розміщення задніх дійок, текстури вим'я, якості кісток, переднього прикріплення ви- мені, глибини тулуба та ширини грудей можуть призвести до корельованого росту довголіття голштинських корів у тропічних умовах.

Запровадження методики лінійної класифрікації у селекційний процес поліпшення українських молочних порід [39] дозволяє виявити бажаний розвиток тих лінійних ознак, від яких залежить тривалість життя тварин, щоб враховувати їх в процесі добору та підбору. Тому метою наших досліджень стало вивчення залежності тривалості життя корів української чорно-рябої молочної (УЧРМ) та голштинської (Г) порід від рівня оцінки лінійних ознак, які характеризують морфологічні якості вимені у загальній системі лінійної класифікації екстер'єрного типу.

Матеріали та методи досліджень. Експериментальні дослідження проведені у стаді господарства компанії "Укрлендфармінг” ПП "Буринське” Підліснівського відділення Сумського району з розведення української чорно-рябої молочної (n=278) та голштинської $(n=293)$ порід. Оцінка екстер'єрного типу корів-первісток проводилася за методикою лінійної класифікації [39] згідно останніх рекомендацій ICAR [46] у віці 2-4 місяців після отелення. Експериментальні показники опрацьовували методами біометричної статистики на ПК за формулами, наведеними Е. К. Меркурьевой [9].

Результати досліджень. Оцінка морфологічних 03нак вимені корів молочних порід в системі лінійної класифікації займає визначне місце, оскільки у фінальній оцінці типу її питома вага складає у більшості країн світу 40\% [42]. Науковий та практичний досвід селекції молочної худоби неодноразово підтверджував, що морфологічні ознаки вимені $€$ найбільш важливими і надійними екстер'єрними показниками високої удійності та технологічності корів [23, 35, 36, 28, $22,30,62]$. Бажане вим'я корови молочного типу в сукупності морфологічних ознак повинно бути великим за об'ємом, пропорційно сформованим, ванно- або чашоподібної форми, величина характеризується розвитком як завширшки, так і в довжину, з розповсюдженням частин далеко уперед по череву і назад за лінію стегна; дно розміщене на достатній відстані від землі, передня частина вимені щільно прилягає до черева, а задня високо і міцно прикріплена з чітко вираженою, глибокою борозною підтримуючої зв'язки; дійки розташовані у центрі часток вимені на оптимальній відстані, циліндрової форми, бажаної довжини і товщини, спрямовані вертикально вниз [23].

За результатами лінійної класифікації описових ознак екстер'єрного типу, які характеризують морфологічні якості вимені корів-первісток піддослідних порід стада ПП "Буринське": прикріпленням передніх часток вимені, висотою прикріплення задніх часток, центральною зв'язкою, глибиною вимені, розташуванням та довжиною передніх дійок, встановлено певну співвідносну мінливість між рівнем оцінки цих ознак та тривалістю життя тварин.

Одна із досить важливих описових ознак вимені, прикріплення передньої частини до черева корови, оцінюється за міцністю, яка характеризується кутом, що утворюється на місці цього з'єднання. Саму високу оцінку (9 балів) за розвиток цієї статі отримує тварина, у якої вим'я характеризується поступовим переходом залозистої тканини передньої частини у черево за допомогою з'єднуючих бокових зв'язок з утворенням тупого кута вищого за $161^{\circ}$ [60]. Міцне прикріплення вимені за звичай відрізняється відмінним 
розвитком передніх часток, ванноподібною формою i, за свідченням наукових досліджень, достовірно корелює 3 молочною продуктивністю [16, 28, 29, 30, 32]. Функціональною особливістю міцного прикріплення передніх часток вимені є запобігання обвисанню його з віком.

Результати оцінки ознаки прикріплення передніх часток вимені (рис. 1) засвідчили наявність співвідносного зв'язку між розвитком цієї ознаки та тривалістю життя корів оцінюваних порід. Достовірна різниця між коровами, оціненими в один та дев'ять балів, досить значна і становила 841 (УЧРМ; $\mathrm{P}<0,001)$ та 810 (Г; $\mathrm{P}<0,001)$ днів. Міжпородне порівняння тривалості життя корів, залежно від оцінки, свідчить на користь корів голштинської породи з мінливістю у межах 43-159 днів за недостовірної різниці. Про суттєвий вплив на тривалість життя корів ознаки повідомляється у дослідженнях зарубіжних авторів. Так, за оціеки корів джерсейської породи встановлено найвищий зв'язок між прикріплення передніх часток вимені та функціональним життям з генетичними кореляціями за перші три лактації відповідно 0,23; 0,63 та 0,33 [44]. За оцінкою генетичних параметрів італійської бурої швіцької молочної худоби [53] встановлено сильну позитивну генетичну кореляцію між прикріплення передніх часток вимені та надоєм $(0,45)$, але незначною - 3 функціональною довговічністю $(0,10)$.

Наступна лінійна ознака «висота заднього прикріплення вимені» аналогічно з попередньою також виконує утримуючу функцію, не дозволяючи вимені з віком звиснути. Бажаний розвиток даної статі оцінюється найвищим балом. Різниця між найнижчою та найвищою оцінками за даною ознакою, яка отримана за результатами наших досліджень у корів піддослідних порід, становила 740 (УЧРМ; Р<0,001) та 810 (Г; Р<0,001) днів (рис. 2).

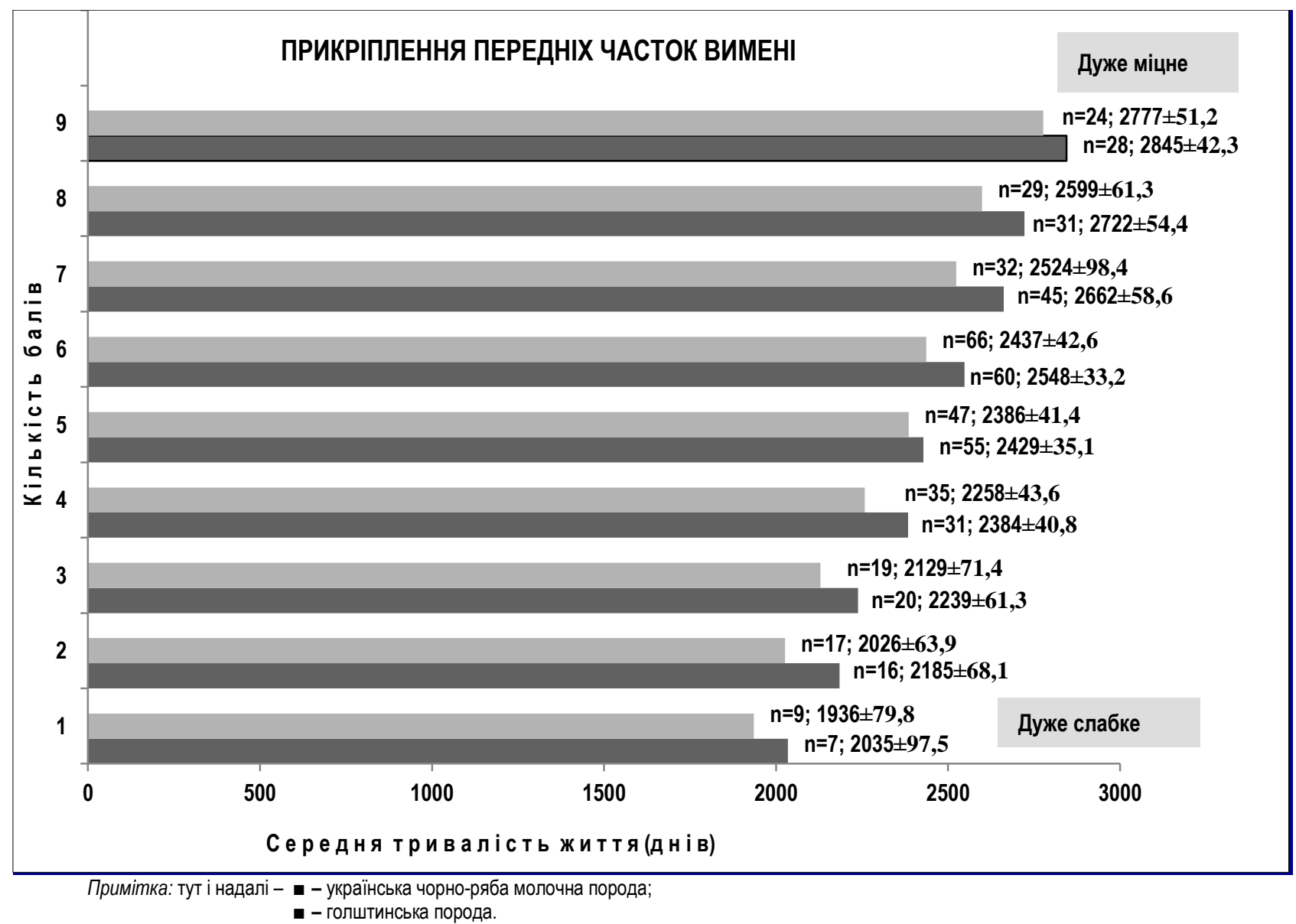

Рис. 1. Співвідносна мінливість бальної оцінки описової ознаки типу «прикріплення передніх часток вимені» з тривалістю життя корів підконтрольних порід 


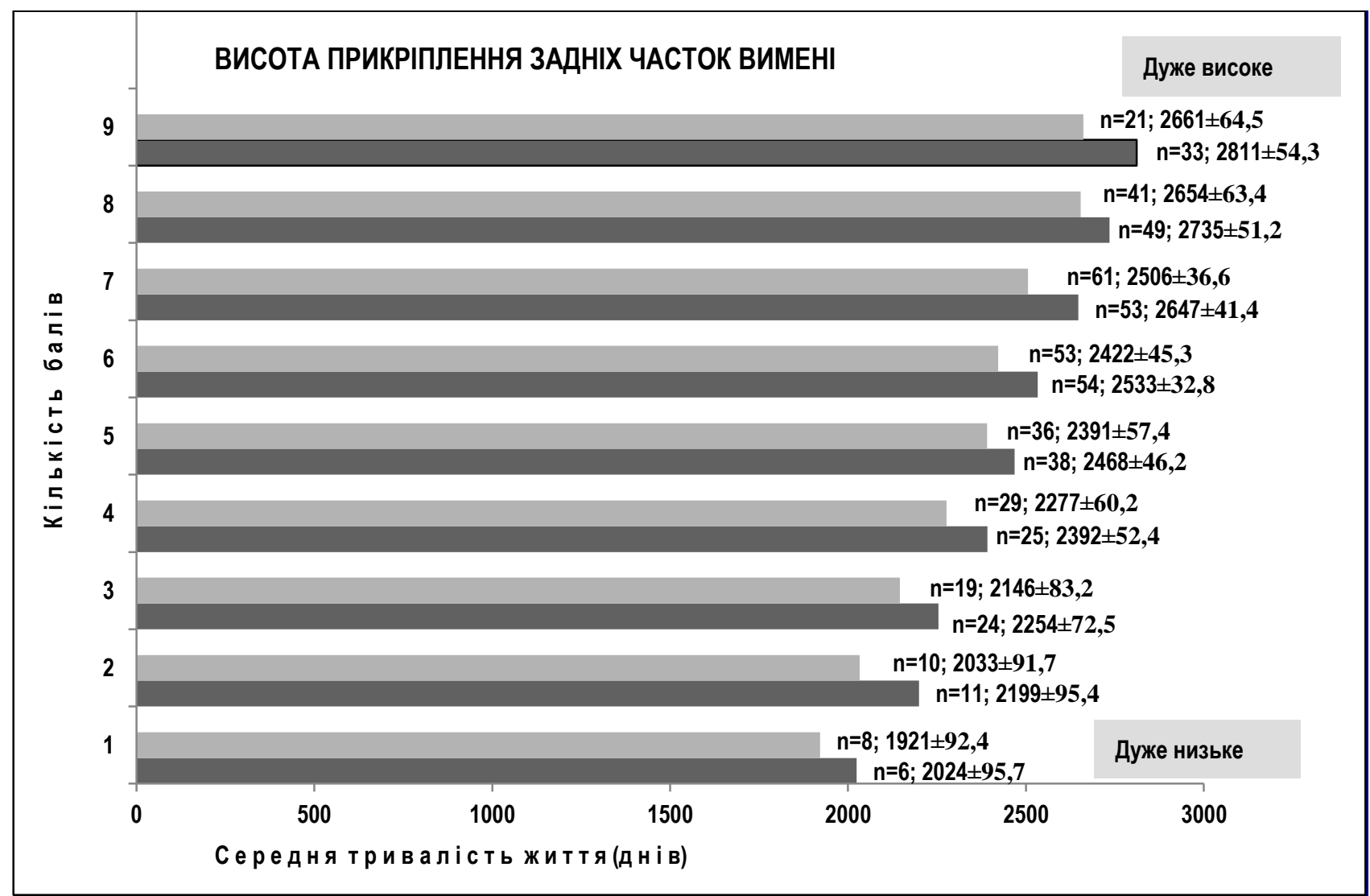

Рис. 2. Співвідносна мінливість бальної оцінки описової ознаки типу «висота прикріплення задніх часток вимені» 3 тривалістю життя корів підконтрольних порід

Центральна зв'язка (підтримуюча зв'язка, роздільна борозна) $є$ наступною лінійною ознакою вимені у корів молочної худоби, яка також пов'язана з утриманням його на відповідній висоті. Високо розташоване вим'я над підлогою полегшує оператору підготовку його до процесу доїння та запобігає під час лежання охолодженню і травмуванню. Високе розташування вимені, з глибокою, міцною, добре вираженою та високо піднятою центральною зв'язкою $є$ бажаним розвитком ознаки 3 найвищою оцінкою у 9 балів.

Шпали гістограми (рис. 3) показують, що середня тривалість життя корів піддослідних порід істотним чином залежить від рівня оцінки за ознаку «центральна зв'язка». Тварини з оцінкою за розвиток центральної зв'язки вимені нижчою за 1-3 бали живуть, відповідно до оцінюваних порід, від 2089 до 2401 (УЧРМ) та від 2154 до 2468 (Г) днів. Корови з оцінкою дев'ять балів обох порід відрізняються найвищою тривалістю життя - 2663 дні (УЧРМ), поступаючись коровам з самою низькою оцінкою на 754 дні $(P<0,001)$ та 2803 дні (Г) з достовірним перевищенням на 649 днів ( $\mathrm{P}<0,001)$.

Відповідно узгоджуючись з нашими результатами, Schneider et al. [54] та Sewalem et al. [55] виявили, що підтримуюча зв'язка голштинських корів $€$ одною $з$ найважливіших ознак вим'я, так як тварини з нижчими оцінками (з вкрай слабкими зв'язками) майже у два рази більше ризикують бути вибракуваними, ніж тварини з вищими оцінками. 


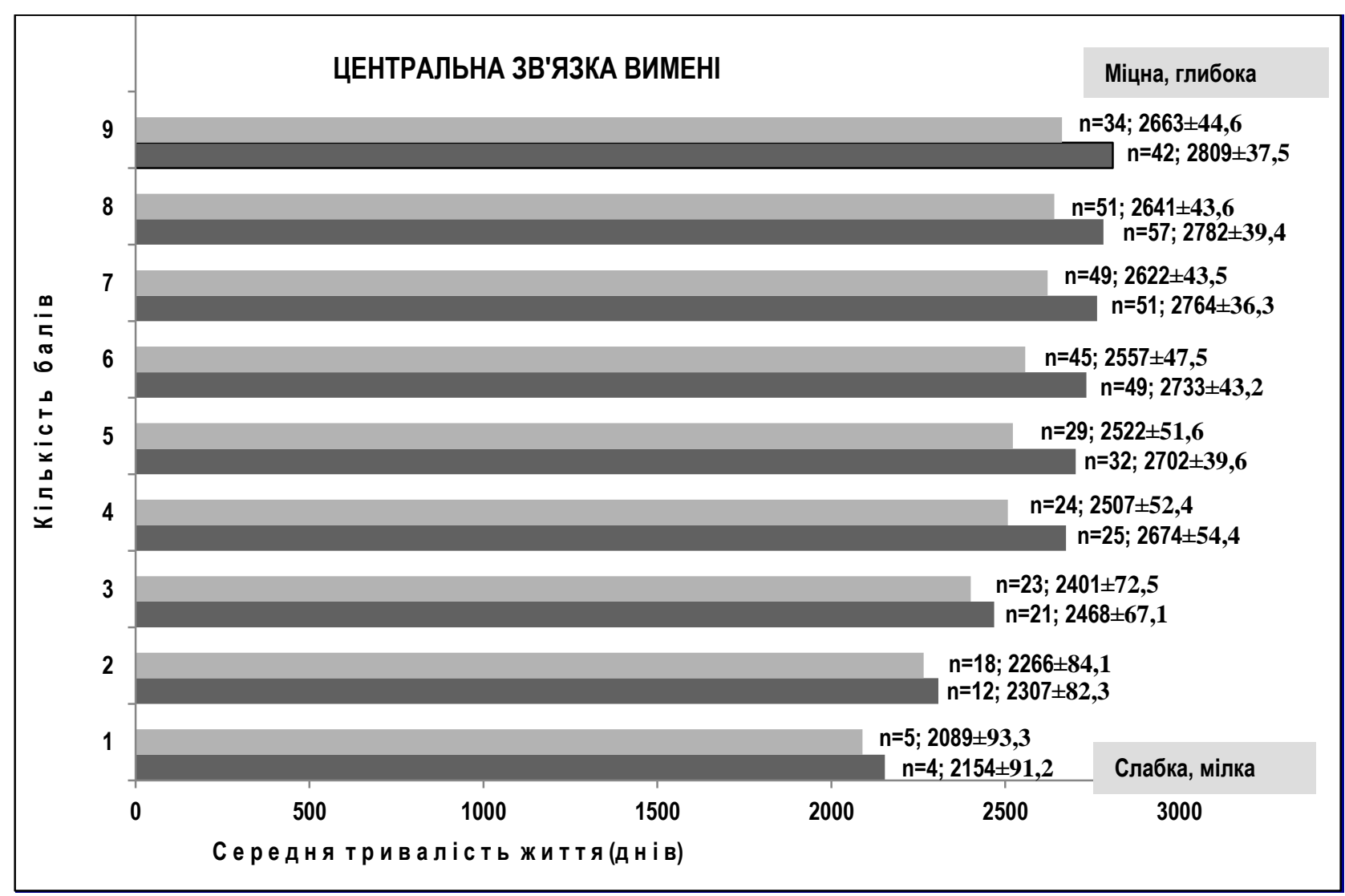

Рис. 3. Співвідносна мінливість бальної оцінки описової ознаки типу «центральна зв'язка вимені» і тривалістю життя корів підконтрольних порід

Розташування дна вимені відносно підлоги являється досить важливою функціональною технологічною лінійною ознакою молочної худоби. Згідно методики лінійної класифікації глибина вимені оцінюється відстанню між відносно умовною лінією, проведеною на рівні скакального суглоба і дном вимені. Як уже було відмічено вище, глибоке, відвисле вим'я завдає багато незручностей при машинному доїнні, часто травмується і більш сприйнятливе до захворювання на мастит. Відстань дна вимені відносно підлоги значним чином залежить від попередніх трьох ознак, які відповідають за міцність його прикріплення. Показники гістограми (рис. 4) свідчать про те, що корови, у яких високо розташоване вим'я, значно менше піддаються вказаним ризикам і тому значно довше використовуються у стаді підконтрольного господарства. Різниця між середньою тривалістю життя корів з оцінкою дев'ять балів та оцінкою в один бал за глибину вимені становить у корів української чорно-рябої молочної породи 739 днів $(\mathrm{P}<0,001)$, у корів голштинської - 832 дні $(\mathrm{P}<0,001)$. Міжпородне порівняння показує перевагу корів голштинської породи над українською чорно-рябою молочною за тривалістю життя у межах усіх значень оцінок за глибину вимені, а за деякими різниця на їхню користь достовірна. За середньою оцінкою п'ять балів різниця склала 170 днів $(P<0,05)$. Співвідносний тісний зв'язок глибини вимені 3 функціональною довговічністю виявили у бурих швіців Італії

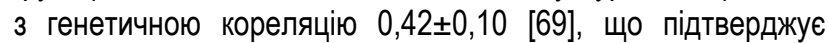
результати наших досліджень.

Чергова лінійна ознака вимені - розташування передніх дійок, є досить важливою як із селекційної точки зору, так і з технологічної (рис. 5). Загалом, розміщення дійок на вим'ї може бути: широке, майже квадратне; широке передніх і зближене задніх; зближене бічних при нормальній відстані між дійками лівого і правого боку; зближене розміщення всіх дійок. Небажана як дуже близька (до 6 см), так і дуже велика (більше 20 см) відстань між вершинами дійок. Дійки, які розташовані на оптимальній відстані (12-16 см), розміщені по центру часток вимені, вертикально спрямовані вниз, циліндричної або конічної форми - найкраще забезпечують вимоги машинного доїння [23]. У системі лінійної класифікації дуже близьке або дуже широке розташування передніх та задніх дійок не $є$ кращим розвитком ознаки. Проте, якщо вибирати із крайніх варіантів, то кращий це широке розташування ніж вузьке.

Результати діаграми показують, що тривалість життя корів обох порід у стаді підконтрольного господарства залежно від оцінки за розташування передніх дійок характеризується незначною криволінійною мінливістю. Тобто найдовше використовуються у стаді корови обох порід з середньою оцінкою 7 балів. Надалі спостерігаються відхилення з недостовірною різницею у бік зменшення тривалості життя 3 оцінками 8-9 та 6-5 балів 3 перевагою корів голштинської породи. Істотне зниження показника тривалості життя у корів розпочинається з оцінками за цю ознаку від чотирьох до одного балу.

Якщо узяти за порівняння кращий варіант співвідносного зв'язку розташування передніх дійок з тривалічтю життя 3 оцінкою 7 балів, то достовірна різниця розпочинається 3 порівняння цієї групи корів із групами з оцінкою 5-1 бал. Тварини української чорно-рябої молочної породи оціненої у 7 балів переважали п'ять груп корів з оцінками 5-1 бал, які склали від $202(P<0,01)$ до 872 днів $(P<0,001)$, тварини голштинської породи за аналогічного порівняння становила від $228(\mathrm{P}<0,01)$ до 891 дня $(\mathrm{P}<0,001)$.

Вісник Сумського національного аграрного університету 


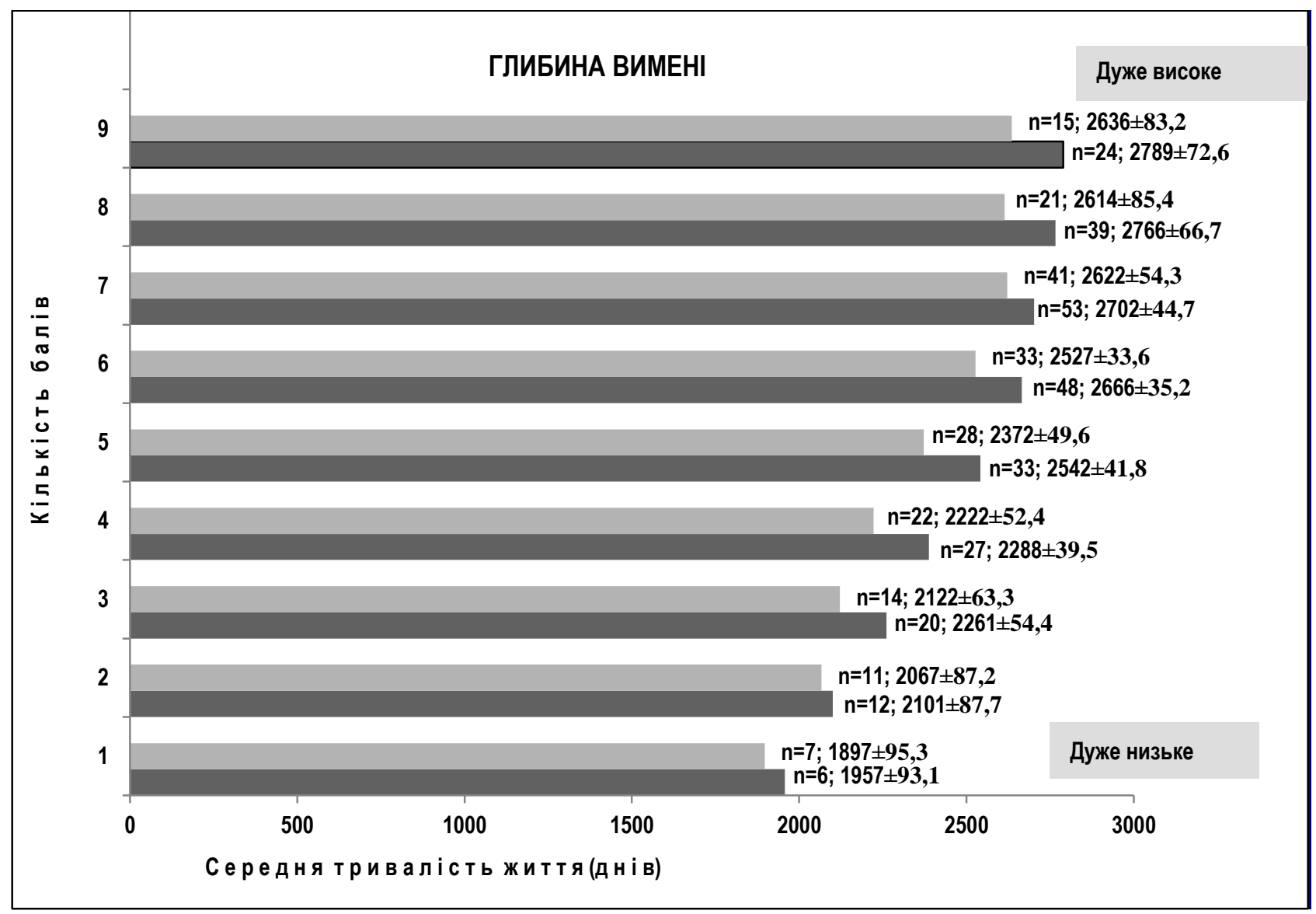

Рис. 4. Співвідносна мінливість бальної оцінки описової ознаки типу «глибина вимені» і тривалістю життя корів підконтрольних порід

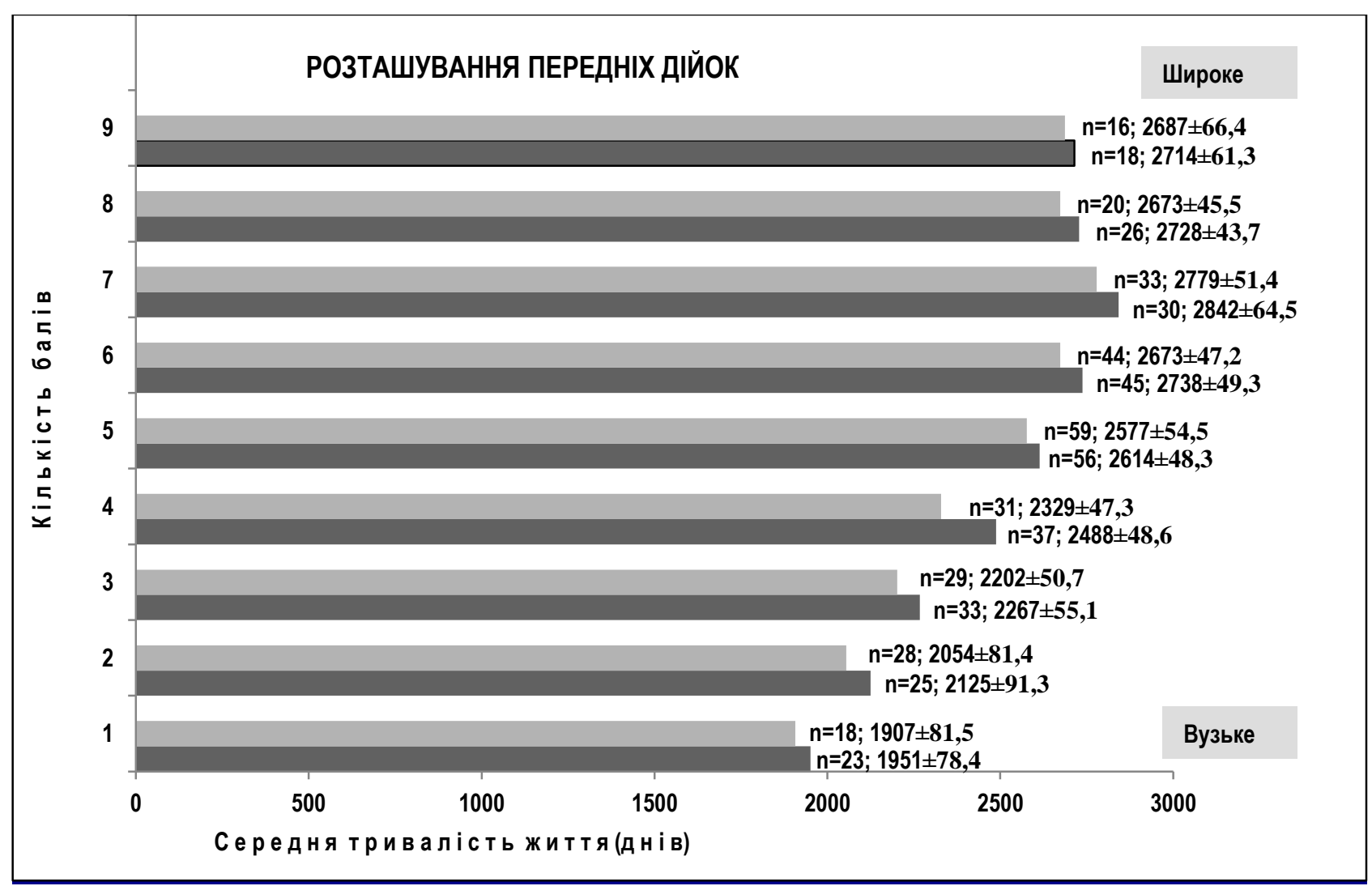

Рис. 5. Співвідносна мінливість бальної оцінки описової ознаки типу «розташування передніх дійок» і тривалістю життя корів підконтрольних порід 
Наступна лінійна ознака вимені - довжина дійок, відноситься до технологічних ознак. Сучасна молочна худоба різних порід характеризується відповідно різними за розмірами довжини показниками передніх та задніх дійок. Дослідженнями [19] довжина дійок корів-первісток української чорно-рябої молочної породи становила 5,6 см, а голштинської 5,8 см. За даними досліджень [11] морфологічних властивостей вимені корів швіцької породи різного екологічного походження у віці першої лактації встановлено, що довжина передніх дійок становила $7,5 \mathrm{~cm}$, а задніх - 5,5 cм, а довжина дійок корів завазених із Австрії відповідно становила 6,7 та 5,8 см. У симентальських первісток ці показники були за довжиною передніх дійок 6,7-7,5 см та задніх 6,3-6,9 см залежно від року оцінки [1]. Дослідженями корів-первісток українських чорно- та червоно рябої молочних порід [6] довжина передніх та задніх дійок відповідно становила 5,6 і
4,7 та 5,8 і 4,6 см. У корів-первісток української червоної молочної породи [15] довжина передніх дійок варіювала у межах 6,15-6,69 та задніх - 5,75-6,0 см.

На підставі експериментальних даних лінійної оцінки та кореляційних зв'язків між ними і надоєм встановлено бажану вираженість екстер'єрного типу корів-первісток створеної української чорно-рябої молочної породи в загальній єдності основних описових статей, які входять до складу системи лінійної класифікації, за якими довжина передніх дійок має становити 5 см з оцінкою пять балів [21, 23]. Аналізуючи показники досліджень корів українських молочних та голштинської порід можна зробити висновок, що довжина передніх та задніх дійок відповідає бажаному типу варіюючи у межах 5-6 см, що відповідає відповідно 5-6 балам лінійної оцінки.

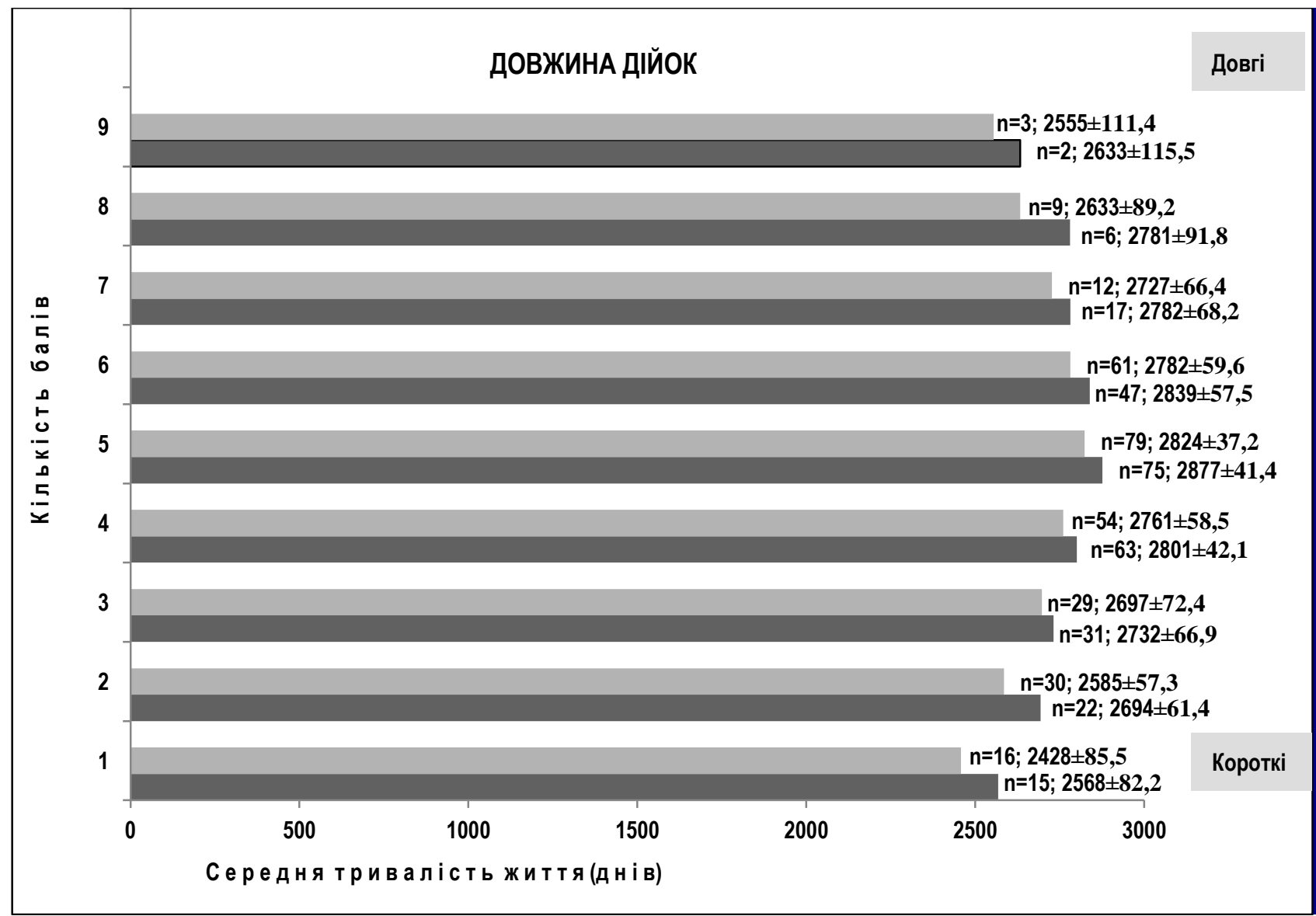

Рис. 6. Співвідносна мінливість бальної оцінки описової ознаки типу «довжина дійок» і тривалістю життя корів підконтрольних порід

Оцінка співвідносної мінливості довжини передніх дійок з тривалістю життя корів підконтрольних порід свідчить про те, що довше функціональне життя було у корів з середньою оцінкою п'ять балів, що дорівнює їхній довжині на рівні 5 см. Збільшення оцінки за дану ознаку до 6-9 балів у корів української чорно-рябої молочної породи вплинуло на тривалість життя незначною мірою, від 42 до 269 днів, 3 мінімальним ступенем достовірності при $\mathrm{P}<0,05$ у порівнянні з групами тварин, оцінених у 8 та 9 балів. Аналогічне порівняння корів голштинської породи оцінених у п'ять балів 3 групами тварин оцінених у 6-9 балів засвідчило різницю у межах 38-241 дня 3 достовірністю лише у порівнянні 3 тва- ринами оціненими у 9 балів при $P<0,05$. Зниження оцінки викликало дещо меншу тривалість життя у корів обох порід 3 достовірністю лише при порівнянні з групою тварин оцінених в один бал на 396 (УЧРМ; $P<0,001)$ та 309 (Г; $P<0,001)$ днів та при порівнянні з групою, оцінених у два бали з різницею відповідно 239 (УЧРМ; Р<0,001) та 183 (Г; Р<0,05) дні.

Узагальнюючи результати досліджень важливо відмітити, що кожна із оцінюваних описових ознак у корів обох порід чинить вплив на тривалість життя з різною мінливістю у межах кожної конкретної статі.

Висновки. 1. Встановлено співвідносну мінливість бальної оцінки лінійних ознак, які характеризують морфоло- 
гічну будову вимені, та тривалістю життя корів у порівняльному аналізі української чорно-рябої молочної та голштинської порід. 3 незначною перевагою та, в окремих випадках, 3 достовірною різницею тварин голштинської породи мали перевагу над українською чорно-рябою молочною худобою за тривалістю життя у залежності від оцінки лінійних ознак вимені.
2. Ступінь співвідносної мінливості між рівнем оцінки морфологічних статей вимені та тривалістю життя тварин залежала від конкретної лінійної ознаки.

3. Задля збільшення тривалості життя корів молочного стада важливо підбирати бугаїв-плідників з високою оцінкою за типом, особливо з урахуванням бажаного розвитку лінійних ознак вимені у їхніх дочок.

\section{Список використаної літератури:}

1. Даньків В. Я., Когут М. І. Оцінка придатності корів-первісток симентальської породи до машинного доїння. Передгірне та гірське землеробство і тваринництво. 2016. Вип. 59.С. 185-189.

2. Державний реєстр суб'єктів племінної справи у тваринництві за 2019 рік. Романова О. В., Прийма С. В., Полупан Ю. П., Басовський Д. М.; загальна редакція Прийми С. В. Київ, 2020. Том II. 199 с. [Електронний ресурс] - Режим доступу: http://animalbreedingcenter.org.ua/images/files/deriplemreestr/deriplemreestr_tom2_2019.pdf (дата звернення 02.03.2021).

3. Казаровец Н. В., Павлова Т. В., Моисеев К. А. Мониторинг производственного использования коров в условиях дойных стад с высокопродуктивным маточным поголовьемИзвестия национальной академии наук беларуси. Серия аграрных наук. 2019. Т. 57. №2. С. 204-215.

4. Климов Н. Н., Танана Л. А., Василец Т. М. Влияние паратипических фракторов на продуктивное долголетие коров белорусской чёрно-пёстрой породы. Ученые записки учреждения образования "Витебская ордена "Знак почета" государственная академия ветеринарной медицины". 2010. Т. 46. № 1-2. С. 142-145.

5. Клопенко Н. І., Ставецька Р. В. Генетична детермінація господарського використання корів молочного напряму продуктивності за вбирного схрещування. Технологія виробництва і переробки продукції тваринництва: Зб. наук. праць Білоцерк. нац. аграр. ун-т. Біла Церква, 2015. Вип. №1. С. 23-28.

6. Ковальчук Т.І. Морфо-функціональні властивості вимені корів української чорно-рябої та української червоно-рябої молочних порід різних генотипів. Вісник ДАУ. 2006. №1. С. 273-279.

7. Ладика В. І., Хмельничий Л. М., Салогуб А. М. Сполучна мінливість статей екстер'єру корів з молочною продуктивністю. Збірник наукових праць Білоцерківського НАУ. Біла Церква 2010. Вип. 3 (72). С. 9-11.

8. Ладика В. І., Хмельничий С. Л. Тривалість життя корів української чорно-рябої молочної породи в залежності від рівня оцінки лінійних ознак типу, які характеризують стан кінцівок. Розведення і генетика тварин. Вінниця, 2016. Вип. 51. С. 8392.

9. Меркурьева Е. К. Генетические основы селекции в скотоводстве. М.: Колос, 1977. 240 с.

10. Москаленко Л. П., Фураева Н. С., Зверева Е. А. Комплексная оценка влияния генетических и паратипических факторов на продуктивное долголетие голштинизированных коров ярославской породы. Вестник АПК Верхневолжья. 2013. № 3 (23). C. $41-46$.

11. Піщан І. С. Морфрологічні властивості вимені корів швіцької породи австрійської та сумської селекції. Науковотехнічний бюлетень НДЦ біобезпеки та екологічного контролю ресурсів АПК. 2016. №1, Т.4. С. 168-175.

12. Полупан Ю. П. Генетична детермінація тривалості та ефеккивності довічного використання чорно-рябої молочної худоби. Розведення і генетика тварин. К.: 2015. Вип. 49. С. 120-133.

13. Полупан Ю. П. Ефективність довічного використання корів різних країн селекції. Вісник Сумського НАУ. Серія «Тваринництво». 2014. Вип. 2/2 (25). С. 14-20.

14. Полупан Ю. П. Ефективність довічного використання червоної молочної худоби. Розведення і генетика тварин К.: Аграрна наука. 2000. Вип. 33. С. 97-105.

15. Проноза О. Л. Морфологічна оцінка вимені корів української червоної молочної породи різного віку першого осіменіння. Вісник Сумського НАУ. Серія «Тваринництво». 2014. Вип. С. 2/2(25). С. 89-92.

16. Салогуб А. М. Хмельничий Л. М. Особливості успадковуваності та сполучної мінливості ознак екстер'єру корів української червоно-рябої молочної породи. Збірник наукових праць Вінницького НАУ. Серія: Сільськогосподарські науки. Вінниця. 2011. Вип. 8 (48). С. 59-62.

17. Сельцов В. И., Молчанова Н. В., Сулима Н. Н. Влияние методов разведения на продуктивное долголетие и пожизненную продуктивность коров. Зоотехния. 2013. №9. С. 2-4.

18. Скворцова Е. Г. Влияние доли кровности по голштинской породе на продуктивное долголетие черно-пестрого скота. Вестник биотехнологии. 2020. № 1 (22). С. 15-22.

19. Ставецька Р., Клопенко Н. Характеристика вим'я корів української чорно-рябої молочної породи за вбирного схрещування. Тваринництво України. 2015. №12 (72). С. 15-20.

20. Титова С. В. Продуктивное долголетие молочных коров разных генотипов. Экономические науки. 2015. Т. 1. № 2 (2). C. $52-55$.

21. Хмельничий Л. М. Бажаний тип - міра оцінки молочної худоби за екстер'єром. Вісник Українського товариства генетиків і селекціонерів. 2004. № 1. Том. 2. С. 72-83.

22. Хмельничий Л. М. Екстер'єрний тип та продуктивність корів української чорно-рябої молочної породи. Науковотехнічний бюлетень Інституту тваринництва УААН. Харків. 2003. №. 84. С. 142-146.

23. Хмельничий Л. М. Оцінка екстер'єру тварин в системі селекції великої рогатої худоби: дис. доктора сільськогосподарських наук : $06.02 .01 / /$ Л. М. Хмельничий. с. Чубинське, 2005. 430 с. 
24. Хмельничий Л. М. Практичний досвід, стан та перспектива використання методики лінійної класиффікації корів молочної худоби в Україні. Вісник Сумського національного аграрного університету. Серія «Тваринництво». 2013. Вип. 7 (23). С. 11-19.

25. Хмельничий Л. М., Бардаш Д. О. Показники довголіття корів української червоно-рябої молочної породи залежно від частки спадковості голштинської породи. Вісник Сумського НАУ. Серія «Тваринництво». 2019. Вип. 4(39). С.13-19.

26. Хмельничий Л. М., Вечёрка В. В. Долголетие коров украинской красно-пестрой молочной породы в зависимости от линейной оценки описательных признаков конечностей. Актуальные проблемы интенсивного развития животноводства. Сборник науч. трудов Белорусской гос. сельскохоз. академии. Горки. БГСХА, 2016. Вып. 19. Ч. 1. С. 336-340.

27. Хмельничий Л. М., Вечерка В. В. Пожизненная продуктивность и длительность использования коров украинской красно-пестрой молочной породы разных генотипов. Пути продления продуктивной жизни молочных коров на основе оптимизации разведения, технологий содержания и кормления животных [текст]: материалы междунар. науч.- практ. конф., (2829 мая, пос. Дубровицы) / ВИЖ им. Л. К. Эрнста, 2015. С. 159-162.

28. Хмельничий Л. М., Вечорка В. В. Вікова мінливість кореляцій між надоєм та лінійною оцінкою типу корів-первісток українських чорно- та червоно-рябої молочних порід. Технологія виробництва і переробки продуктів тваринництва. Збірник наукових праць БНАУ. Біла Церква. 2014. № 1 (116). С. 84-87.

29. Хмельничий Л. М., Вечорка В. В. Ефективність впливу генеалогічних формувань на показники довголіття та довічної продуктивності корів української червоно-рябої молочної породи. Вісник Сумського НАУ. Серія «Тваринництво». 2016. Вип. 1 (29). С. 3-10.

30. Хмельничий Л. М., Вечорка В. В. Особливості будови тіла корів української чорно-рябої молочної та голштинської порід. Розведення і генетика тварин. К.: Аграрна наука. 2008. Вип. 42. С. 318326.

31. Хмельничий Л. М., Вечорка В.В.Тривалість життя корів української чорно-рябої молочної породи в залежності від рівня оцінки лінійних ознак екстер'єру. Аграрна наука та харчові технології. Вінниця. 2017. Вип. 2(96). С. 249-258.

32. Хмельничий Л. М., Вечорка В.В.Тривалість життя корів української чорно-рябої молочної породи в залежності від рівня лінійної оцінки морфологічних ознак вимені. Науково-теоретичний збірник Житомирського національного агроекологічного університету. ЖНАЕУ. 2015. №.2 (52). Т. 3. С. 57-62.

33. Хмельничий Л. М., Вечорка В. В. Вплив бугаїв-плідників на продуктивне довголіття корів української червоно-рябої молочної породи. Науково-технічний бюлетень НДЦ біобезпеки та екологічного контролю ресурсів АПК. Дніпропетровськ. 2016. T. 4. №1. С. 267-273.

34. Хмельничий Л. М., Вечорка В. В. Вплив якісного розвитку морфологічних ознак вимені корів української червонорябої молочної породи на їхнє довголіття. Аграрна наука та харчові технології. Вінниця. 2016. Вип. 1 (91). С. 211-219.

35. Хмельничий Л. М., Лобода В. П. Оценка влияния наследственных факторов на показатели пожизненной продуктивности коров украинской красно-пестрой молочной породы. Актуальные проблемы интенсивного развития животноводства: сборник научных трудов Белорусской гос. сельхоз. академии. Горки: БГСХА. 2014. Вып. 17. Ч. 2. С. $159-165$.

36. Хмельничий Л. М., Лобода В. П. Удосконалення стада з розведення української червоно-рябої молочної породи за показниками довічної продуктивності. Вісник Сумського національного аграрного університету. Серія «Тваринництво». 2014. Вип. 2/1 (24). С. 91-97.

37. Хмельничий Л. М., Салогуб А. М., Бондарчук В. М., Лобода В. П. Тривалість використання та довічна продуктивність корів залежно від методів підбору та бугаїв-плідників української червоно-рябої молочної породи. Вісник Сумського національного аграрного університету. Серія «Тваринництво». 2015. Вип. 6 (28). С. 65-70.

38. Хмельничий Л. М., Салогуб А. М., Шевченко А. П., Хмельничий С. Л. Мінливість довічної продуктивності корів української чорно-рябої молочної породи залежно від генеалогічних формувань. Вісник Сумського національного аграрного університету. Серія «Тваринництво». 2012. Вип. 10 (20). С. 12-17.

39. Хмельничий Л. М., Ладика В. І., Полупан Ю. П., Салогуб А. М. Методика лінійної класиффікації корів молочних і молочно-м'ясних порід за типом. Суми: ВВП “Мрія-1" ТОВ, 2008. 28 с.

40. Хмельничий С. Л., Повод М. Г., Самохіна Є. А. Продуктивне довголіття корів української чорно-рябої молочної породи залежно від спадковості голштинських бугаїв-плідників. Вісник Сумського НАУ. Серія «Тваринництво». 2020. Вип. 2 (41). C. 81-85.

41. Шульга Л. В., Старовойтов Д. П., Ланцов А. В. Влияние разных способов содержания коров на продолжительность производственного использования. Актуальные проблемы интенсивного развития животноводства, 2015, №.18(1). С. 210-216.

42. A useful guide to Linear Assessment. Holstein UK Scotsbridge House, Scots Hill, Rickmansworth, Herts, WD3 3BB. . [Електронний ресурс]. - Режим доступу: https://www.holstein-uk.org/media/legacyhw/Breeding\%20for\%2OHW/Breeding-LinearAssessment.pdf (Дата звернення: 13.03.2021)

43. Battagin M., Sartori C., Biffani S., Penasa M., Cassandro M. Genetic parameters for body condition score, locomotion, angularity, and production traits in Italian Holstein cattle. Journal of Dairy Science, June 3 2013, Vol. 96, Issue 8, p 5344-5351.

44. Du Toit, J., Van Wyk J.B. and Maiwashe A., 2012. Relationships between functional herd life and conformation traits in the South African Jersey breed. South African Journal of Animal Science 2012, 42 (No.1). pp. 47-54. DOI: 10.4314 / sajas.v42i1.6

45. García-Ruiz A., Ruiz-López F.J., Vázquez-Peláez C.G. and Valencia-Posadas M. (2016), Impact of conformation traits on genetic evaluation of length of productive life of Holstein cattle. International Journal of Livestock Production. Vol. 7(11). https://academicjournals.org/journal//JLP/article-full-text-pdf/338FE3860409

46. ICAR Guidelines for Conformation Recording of Dairy Cattle, Beef Cattle and Dairy Goats, 1/76. Section - 5, 
Conformation Recording, version June, 2018. [Електронний ресурс]. - Режим доступу: https://www.icar.org/Guidelines/05Conformation-Recording.pdf

47. Imbayarwo-Chikosi V. E., Dzama, K., Halimani, T. E., van Wyk, J. B., Maiwashe, A., \& Banga, C. B. (2015). Genetic prediction models and heritability estimates for functional longevity in dairy cattle. South African Journal of Animal Science, 45(2), 106-121.

48. Kadarmideen H. N., Wegmann S. Genetic Parameters for Body Condition Score and its Relationship with Type and Production Traits in Swiss Holsteins. J. Dairy Sci., November 2003, Volume 86, Issue 11, Pages 3685-3693.

49. Kern E. L., Cobuci J. A., Costa C. N., McManus C. M. \& Braccini N. J. Genetic association between longevity and linear type traits of Holstein cows. Scientia Agricola, 2015. 72(3), 203-209.

50. Kern E. L., Cobuci J. A., Costa C. N., McManus C. M., Campos G. S., Almeida T. P., and Campos R. V. 2014. Genetic association between herd survival and linear type traits in Holstein cows under tropical conditions. Italian J. Animal Science. 13:3419. DOI: 10.4081/ijas.2014.3419

51. Miglior F., Muir B. L., Van Doormaal B. J. Selection indices in Holstein cattle of various countries. J. Dairy Sci. 2005, 88:1255-1263.

52. Novaković Ž., Ostojić-Andrić D., Pantelić V., Beskorovajni R., Popović N., Lazarević M., Nikšić D. Lifetime production of high-yielding dairy cows. Biotechnology in Animal Husbandry. 2014. Vol. 30, N 3. P. 399-406. https://doi.org/10.2298/BAH1403399N

53. Samoré A.B., Rizzi R., Rossoni A., Bagnato A., 2010. Genetic parameters for functional longevity, type traits, somatic cell scores, milk flow and production in the Italian Brown Swiss. Italian J. Animal Science. 9: e28. doi: 10.4081/ijas.2010.e28

54. Schneider M. del P., Dürr J.W., Cue R.I., Monardes H.G. Impact of type traits on functional herd life of Quebec holsteins assessed by survival analysis. J. Dairy Sci., 2003. 86: 4083-4089.

55. Sewalem A., Kistemaker G.J., Miglior F., Van Doormaal B.J. Analysis of the relationship between type traits and functional survival in Canadian Holsteins using a Weibull proportional hazards model. J. Dairy Sci., 2004. 87: 3938-3946.

56. Zavadilová L., Němcová E., Štípková M. Effect of type traits on functional longevity of Czech Holstein cows estimated from a Cox proportional hazards model. Journal of Dairy Science, August 2011,Vol. 94, Issue 8, pp. 4090-4099.

57. Zavadilová L., Němcová E., Štípková M., Bouška J. Relationships between longevity and conformation traits in Czech Fleckvieh cows. Czech J. Anim. Sci., 54, 2009 (9): 387-394.

58. Zavadilová L., Štípková M. Genetic correlations between longevity and conformation traits in the Czech Holstein population. Czech J. Anim. Sci., 57, 2012 (3): 125-136.

\section{References:}

1. Dankiv, V. Ya., and Kohut, M. I., 2016. Otsinka prydatnosti koriv-pervistok symentalskoi porody do mashynnoho doinnia [Assessment of the suitability of Simmental firstborn cows for machine milking]. Peredhirne ta hirske zemlerobstvo i tvarynnytstvo, issue 59 , pp. 185-189.

2. Romanova, O.V., Priyma, S.V., Polupan, Yu. P.,and Basovsky, D.M., 2020. State Register of Breeding Entities in Animal Husbandry for 2019 [Derzhavnyi reiestr sub'iektiv pleminnoi spravy u tvarynnytstvi za 2019 rik]. In: S.V. Pryimy, ed. Vol. II., pp. 199. doi: http://animalbreedingcenter.org.ua/images/files/derjplemreestr/derjplemreestr_tom2_2019.pdf (access date 02.03.2021).

3. Kazarovets, N. V., Pavlova, T. V. and Moiseev, K. A., 2019. Monitoring proizvodstvennogo ispol'zovaniya korov v usloviyakh doynykh stad s vysokoproduktivnym matochnym pogolov'em [Monitoring production use of cows in a dairy herd with highly productive broodstock]. Izvestiya natsional'noy akademii nauk Belarusi. Seriya agrarnykh nauk, no 2, pp. 204-215.

4. Klimov, N. N., Tanana, L. A. and Vasilets, T. M., 2010. Vliyanie paratipicheskikh faktorov na produktivnoe dolgoletie korov belorusskoy cherno-pestroy porody [The influence of paratypical factors on productive longevity cows of Belarusian Black-and-White breed]. Uchenye zapiski uchrezhdeniya obrazovaniya "Vitebskaya ordena "Znak pocheta" gosudarstvennaya akademiya veterinarnoy meditsiny", no. 1-2, pp. 142-145.

5. Klopenko N. I., and Stavetska, R. V., 2015. Henetychna determinatsiia hospodarskoho vykorystannia koriv molochnoho napriamu produktyvnosti za vbyrnoho skhreshchuvannia [Genetic determination of economic use cows of the dairy direction productivity for absorbing crossing]. Tekhnolohiia vyrobnytstva i pererobky produktsii tvarynnytstva: Zb. nauk. prats Bilotserk. nats. ahrar. un-t. Bila Tserkva, issue 1, pp. 23-28.

6. Kovalchuk, T. I., 2006. Morfo-funktsionalni vlastyvosti vymeni koriv ukrainskoi chorno-riaboi ta ukrainskoi chervono-riaboi molochnykh porid riznykh henotypiv [Morpho-functional properties udder cows Ukrainian Black- and Red-and-White Ukrainian dairy breeds of different genotypes]. Visnyk DAU, no. 1, pp. 273-279.

7. Ladyka, V. I., Khmelnychyi, L. M. and Salohub, A. M., 2010. Spoluchna minlyvist statei eksterieru koriv z molochnoiu produktyvnistiu [Correlative variability of the conformation body parts cows with milk productivity]. Zbirnyk naukovykh prats Bilotserkivskoho NAU, issue 3(72), pp. 9-11.

8. Ladyka, V. I. and Khmelnychyi, S. L., 2017. Tryvalist zhyttia koriv ukrainskoi chorno-riaboi molochnoi porody v zalezhnosti vid rivnia otsinky liniinykh oznak typu, yaki kharakteryzuiut stan kintsivok [Lifetime of cows Ukrainian Black-and-White dairy breed depending on the score level for linear type traits characterizing limbs condition]. Animal Breeding and Genetics, issue 51, pp. 8392.

9. Merkur'eva, E. K., 1977. Geneticheskie osnovy selektsii v skotovodstve [Genetic bases of selection in animal husbandry]. Moskva: Kolos.

10. Moskalenko, L. P., Furaeva, N. S. and Zvereva, E. A., 2013. Kompleksnaya otsenka vliyaniya geneticheskikh i paratipicheskikh faktorov na produktivnoe dolgoletie golshtinizirovannykh korov yaroslavskoy porody [Comprehensive assessment of 
genetic and paratypical factors influence on the productive longevity of Holsteinized cows of Yaroslavl breed]. Vestnik APK Verkhnevolzh'ya, no. 3(23), pp. 41-46

11. Pishchan, I. S., 2016. Morfolohichni vlastyvosti vymeni koriv shvitskoi porody avstriiskoi ta sumskoi selektsii [Morphological properties cows udder of Swiss breed of Austrian and Sumy selection]. Naukovo-tekhnichnyi biuleten NDTs biobezpeky ta ekolohichnoho kontroliu resursiv APK, no 1, pp. 168-175.

12. Polupan, Yu. P., 2015. Henetychna determinatsiia tryvalosti ta efektyvnosti dovichnoho vykorystannia chorno-riaboi molochnoi khudoby [Genetic determination of the duration and effectiveness of lifetime use of Black-and-White dairy cattle]. Rozvedennia i henetyka tvaryn. Mizhvidomchyi tematychnyi naukovyi zbirnyk, issue 49, pp. 120-133.

13. Polupan, Yu. P., 2014. Efektyvnist dovichnoho vykorystannia koriv riznykh krain selektsii [Effectiveness of cows lifetime use in different countries of selection]. Visnyk Sumskoho natsionalnoho ahrarnoho universytetu. Seriia : Tvarynnytstvo, issue $2 / 2$ (25), pp. 14-20.

14. Polupan, Yu. P., 2000. Efektyvnist dovichnoho vykorystannia chervonoi molochnoi khudoby [Efficiency of lifetime use of Red dairy cattle]. Rozvedennia i henetyka tvaryn, issue 33, pp. 97-105.

15. Pronoza, O. L., 2014. Morfolohichna otsinka vymeni koriv ukrainskoi chervonoi molochnoi porody riznoho viku pershoho osimeninnia. Visnyk Sumskoho NAU. Seriia «Tvarynnytstvo», issue 2(25), pp. 89-92.

16. Salohub, A. M. and Khmelnychyi, L. M., 2011. Osoblyvosti uspadkovuvanosti ta spoluchnoi minlyvosti oznak eksterieru koriv ukrainskoi chervono-riaboi molochnoi porody [Peculiarities of heritability and correlative variability of conformation traits of Ukrainian Red-and-White dairy breed cows]. Zbirnyk naukovykh prats Vinnytskoho NAU. Seriia: Silskohospodarski nauky. Vinnytsia, issue 8 (48), pp. 59-62.

17. Sel'tsov, V. I., Molchanova, N. V., and Sulima, N. N., 2013. Vliyanie metodov razvedeniya na produktivnoe dolgoletie i pozhiznennuyu produktivnost' korov [The influence of breeding methods on productive longevity and lifetime productivity of cows]. Zootekhniya, issue 9, pp. 2-4.

18. Skvortsova, E. G., 2020. Vliyanie doli krovnosti po golshtinskoy porode na produktivnoe dolgoletie cherno-pestrogo skota [Influence of the blood proportion in the Holstein breed on the productive longevity of Black-and-White cattle]. Vestnik biotekhnologii, no. 1(22), pp. 15-22.

19. Stavetska, R. and Klopenko, N., 2015. Kharakterystyka vymia koriv ukrainskoi chorno-riaboi molochnoi porody za vbyrnoho skhreshchuvannia [Characteristics of the udder of cows Ukrainian Black-and-White dairy cattle at absorbing crossing]. Tvarynnytstvo Ukrainy, no 12(72), pp. 15-20.

20. Titova, S. V., 2015. Produktivnoe dolgoletie molochnykh korov raznykh genotipov [Productive longevity dairy cows of different genotypes]. Ekonomicheskie nauki, no. 2, pp. 52-55.

21. Khmelnychyi, L. M., 2004. Bazhanyi typ - mira otsinky molochnoi khudoby za eksterierom [The desired type - measure of dairy cattle assessment by conformation]. Visnyk Ukrainskoho tovarystva henetykiv i selektsioneriv, no. 1, pp. 72-83.

22. Khmelnychyi, L. M., 2003. Eksteriernyi typ ta produktyvnist koriv ukrainskoi chorno-riaboi molochnoi porody [Conformation type and productivity of cows Ukrainian Black-and-White dairy breed]. Naukovo-tekhnichnyi biuleten Instytutu tvarynnytstva UAAN. Kharkiv, no. 84, pp. 142-146.

23. Khmelnychyi, L. M., 2005. Estimation the conformation of animals in the breeding system of cattle. Ph.D. Thesis. Instytut rozvedennia i henetyky tvaryn imeni M.V. Zubtsia NAAN, Chubins'ke.

24. Khmelnychyi, L. M., 2013. Praktychnyi dosvid, stan ta perspektyva vykorystannia metodyky liniinoi klasyfikatsii koriv molochnoi khudoby v Ukraini. Visnyk Sumskoho natsionalnoho ahrarnoho universytetu [Practical experience, condition and prospects of using the method of linear classification of dairy cattle in Ukraine]. Seriia «Tvarynnytstvo», issue 7(23), pp. 11-19.

25. Khmelnychyi, L. M. and Bardash, D. O., 2019. Pokaznyky dovholittia koriv ukrainskoi chervono-riaboi molochnoi porody zalezhno vid chastky spadkovosti holshtynskoi porody [Indicators longevity of cows Ukrainian Red-and-White dairy breed depending on the share of inheritance Holstein breed]. Visnyk Sumskoho NAU. Seriia «Tvarynnytstvo», issue 4(39), pp. 13-19.

26. Khmelnychyi, L. M. and Vechorka, V. V., 2016. Dolgoletie korov ukrainskoj krasno-pestroj molochnoj porody v zavisimosti ot linejnoj ocenki opisatel'nyh priznakov konechnostej [Longevity of cows Ukrainian Red-and-White dairy breed depending on the linear assessment of limb's descriptive traits]. Aktual'nye problemy intensivnogo razvitija zhivotnovodstva. Sbornik nauch. trudov Belorusskoj gos. sel'skohoz. akademii. Gorki. BGSHA, issue. 19(1), pp. 336-340.

27. Khmel'nichiy, L. M. and Vecherka, V. V., 2015. Pozhiznennaya produktivnost' i dlitel'nost' ispol'zovaniya korov ukrainskoy krasno-pestroy molochnoy porody raznykh genotipov [Lifetime productivity and duration of use cows Ukrainian Red-and-White dairy breed of different genotypes]. In: All-Russian Institute of Animal Husbandry named after L. K. Ernst, Ways to extend the productive life of dairy cows based on the optimization of breeding, keeping and feeding technologies, Proceedings of the International conference, Dubrovitsy, May 28-29, pp. 159-162.

28. Khmelnychyi, L. M. and Vechorka, V. V., 2014. Vikova minlyvist koreliatsii mizh nadoiem ta liniinoiu otsinkoiu typu korivpervistok ukrainskykh chorno- ta chervono-riaboi molochnykh porid [Age variability of correlations between milk yield and linear assessment of type cows firstborn of Ukrainian Black- Red-and-White dairy breeds]. Tekhnolohiia vyrobnytstva i pererobky produktiv tvarynnytstva. Zbirnyk naukovykh prats BNAU. Bila Tserkva, no. 1(116), pp. 84-87.

29. Khmelnychyi, L. M. and Vechorka, V. V., 2016. Efektyvnist vplyvu henealohichnykh formuvan na pokaznyky dovholittia ta dovichnoi produktyvnosti koriv ukrainskoi chervono-riaboi molochnoi porody [Effectiveness of genealogical formations influencing on the indicators of longevity and lifetime productivity cows of Ukrainian Red-and-White dairy breed]. Visnyk Sumskoho NAU. Seriia «Tvarynnytstvo», issue 1(29), pp. 3-10.

30. Khmelnychyi, L. M. and Vechorka, V. V., 2008. Osoblyvosti budovy tila koriv ukrainskoi chorno-riaboi molochnoi ta hol- 
shtynskoi porid [Features of the body structure cows Ukrainian dairy Black-and-White and Holstein breeds]. Rozvedennia i henetyka tvaryn, issue 42, pp. 318-326.

31. Khmelnychyi, L. M. and Vechorka, V. V., 2017. Tryvalist zhyttia koriv ukrainskoi chorno-riaboi molochnoi porody v zalezhnosti vid rivnia otsinky liniinykh oznak eksterieru [Lifetime of cows Ukrainian Black-and-White dairy breed depending on the assessment level of conformation linear traits]. Ahrarna nauka ta kharchovi tekhnolohii. Vinnytsia, issue 2(96), pp. 249-258.

32. Khmelnychyi, L. M. and Vechorka, V. V., 2015. Tryvalist zhyttia koriv ukrainskoi chorno-riaboi molochnoi porody $\mathrm{V}$ zalezhnosti vid rivnia liniinoi otsinky morfolohichnykh oznak vymeni [Lifetime of cows Ukrainian Black-and-White dairy breed depending on linear assessment level of udder morphological traits]. Naukovo-teoretychnyi zbirnyk Zhytomyrskoho natsionalnoho ahroekolohichnoho universytetu, no. 2(52), pp. 57-62.

33. Khmelnychyi, L. M. and Vechorka, V. V., 2016. Vplyv buhaiv-plidnykiv na produktyvne dovholittia koriv ukrainskoi chervono-riaboi molochnoi porody [Influence of sires on productive longevity of cows Ukrainian Red-and-White dairy breed]. Naukovotekhnichnyi biuleten NDTs biobezpeky ta ekolohichnoho kontroliu resursiv APK. Dnipropetrovsk, no. 1, pp. 267-273.

34. Khmelnychyi, L. M. and Vechorka, V. V., 2016. Vplyv yakisnoho rozvytku morfolohichnykh oznak vymeni koriv ukrainskoi chervono-riaboi molochnoi porody na yikhnie dovholittia [Influence of qualitative development morphological udder traits cows of Ukrainian Red-and-White dairy breed on their longevity]. Ahrarna nauka ta kharchovi tekhnolohii. Vinnytsia, issue 1(91), pp. 211219.

35. Khmelnychyi, L. M. and Loboda, V. P., 2014. Otsenka vliyaniya nasledstvennykh faktorov na pokazateli pozhiznennoy produktivnosti korov ukrainskoy krasno-pestroy molochnoy porody [Assessment of hereditary factors influence on lifetime productivity indicators of cows Ukrainian Red-and-White Dairy breed]. Aktual'nye problemy intensivnogo razvitiya zhivotnovodstva: sbornik nauchnykh trudov Belorusskoy gos. sel'khoz. akademii. Gorki : BGSKhA, issue 17(2), pp. 159-165.

36. Khmelnychyi, L. M. and Loboda, V. P., 2014. Udoskonalennia stada z rozvedennia ukrainskoi chervono-riaboi molochnoi porody za pokaznykamy dovichnoi produktyvnosti [Improvement of the herd on breeding of Ukrainian Red-and-White Dairy breed by indicators of lifetime productivity]. Visnyk Sumskoho natsionalnoho ahrarnoho universytetu. Seriia «Tvarynnytstvo», issue 2(24), pp. 91-97.

37. Khmelnychyi, L. M., Salohub, A. M., Bondarchuk, V. M. and Loboda, V. P., 2015. Tryvalist vykorystannia ta dovichna produktyvnist koriv zalezhno vid metodiv pidboru ta buhaiv-plidnykiv ukrainskoi chervono-riaboi molochnoi porody [Duration of use and cow's lifetime productivity depending on the selection methods and sires of Ukrainian Red-and-White dairy breed]. Visnyk Sumskoho natsionalnoho ahrarnoho universytetu. Seriia "Tvarynnytstvo", issue 6(28), pp. 65-70.

38. Khmelnychyi, L. M., Salohub, A. M., Shevchenko, A. P., Khmelnychyi, S. L., Bilonoh, O. O., Burlachenko, K. Yu. and Koval, O. M., 2012. Minlyvist dovichnoi produktyvnosti koriv ukrainskoi chorno-riaboi molochnoi porody zalezhno vid henealohichnykh formuvan [Variability lifetime productivity of cows Ukrainian Black-and-White dairy breed based on genealogical groups]. Visnyk Sumskoho natsionalnoho ahrarnoho universytetu. Seriia "Tvarynnytstvo", issue 10(20), pp. 12-17.

39. Khmelnychyi, L. M., Ladyka, V. I., Polupan, Yu. P. and Salohub, A. M., 2008. Metodyka liniinoi klasyfikatsii koriv molochnykh i molochno-miasnykh porid za typom [The method of linear classification cows of dairy and dairy-meat breeds by type]. Sumy: VVP "Mriia-1" TOV.

40. Khmelnychyi, S. L., Povod, M. H. and Samokhina, Ye. A., 2020. Produktyvne dovholittia koriv ukrainskoi chorno-riaboi molochnoi porody zalezhno vid spadkovosti holshtynskykh buhaiv-plidnykiv [Productive longevity of Ukrainian Black-and-White dairy cows depending on the Holstein sires inheritance]. Visnyk Sumskoho NAU. Seriia «Tvarynnytstvo», issue 2(41), pp. 81-85.

41. Shul'ga L. V., Starovoytov, D. P. and Lantsov, A. V., 2015. Vliyanie raznykh sposobov soderzhaniya korov na prodolzhitel'nost' proizvodstvennogo ispol'zovaniya [Influence of different ways of keeping cows on the duration of production use]. Aktual'nye problemy intensivnogo razvitiya zhivotnovodstva, no. 18(1), pp. 210-216.

42. A useful guide to Linear Assessment. Holstein UK Scotsbridge House, Scots Hill, Rickmansworth, Herts, WD3 3BB. doi: https://www.holstein-uk.org/media/legacyhw/Breeding\%20for\%20HW/Breeding-Linear-Assessment.pdf (access date: 13.03.2021)

43. Battagin, M., Sartori, C., Biffani, S., Penasa, M. and Cassandro, M. 2013. Genetic parameters for body condition score, locomotion, angularity, and production traits in Italian Holstein cattle. Journal of Dairy Science, 96(8): 5344-5351.

44. Du Toit, J., Van Wyk, J. B. and Maiwashe, A. 2012. Relationships between functional herd life and conformation traits in the South African Jersey breed. South African Journal of Animal Science, 42(1): 47-54. DOI: 10.4314 / sajas.v42i1.6

45. García-Ruiz, A., Ruiz-López, F. J., Vázquez-Peláez, C. G. and Valencia-Posadas, M. 2016. Impact of conformation traits on genetic evaluation of length of productive life of Holstein cattle. International Journal of Livestock Production, 7(11). DOI: https://academicjournals.org/journal/IJLP/article-full-text-pdf/338FE3860409

46. ICAR Guidelines for Conformation Recording of Dairy Cattle, Beef Cattle and Dairy Goats, 1/76. Section - 5, Conformation Recording, version June, 2018. DOI: https://www.icar.org/Guidelines/05-Conformation-Recording.pdf

47. Imbayarwo-Chikosi V. E., Dzama, K., Halimani, T. E., van Wyk, J. B., Maiwashe, A. and Banga, C. B. 2015. Genetic prediction models and heritability estimates for functional longevity in dairy cattle. South African Journal of Animal Science, 45(2), 106121.

48. Kadarmideen, H. N. and Wegmann, S. 2003. Genetic parameters for body condition score and its relationship with type and production traits in Swiss Holsteins. J. Dairy Sci., 86(11): 3685-3693.

49. Kern, E. L., Cobuci, J. A., Costa, C. N., McManus, C. M. and Braccini, N. J. 2015. Genetic association between longevity and linear type traits of Holstein cows. Scientia Agricola, 72(3): 203-209.

50. Kern, E. L., Cobuci, J. A., Costa, C. N., McManus, C. M., Campos, G. S., Almeida, T. P. and Campos, R. V. 2014. Genetic association between herd survival and linear type traits in Holstein cows under tropical conditions. Italian J. Animal Science, 
13:3419. DOI: $10.4081 /$ ijas.2014.3419

51. Miglior, F., Muir, B. L. and Van Doormaal, B. J. 2005. Selection indices in Holstein cattle of various countries. J. Dairy Sci., 88:1255-1263.

52. Novaković, Ž., Ostojić-Andrić D., Pantelić V., Beskorovajni R., Popović N., Lazarević M., Nikšić D. 2014. Lifetime production of high-yielding dairy cows. Biotechnology in Animal Husbandry. 3: 399-406. DOl: https://doi.org/10.2298/BAH1403399N

53. Samoré, A.B., Rizzi R., Rossoni A. and Bagnato, A. 2010. Genetic parameters for functional longevity, type traits, somatic cell scores, milk flow and production in the Italian Brown Swiss. Italian J. Animal Science. 9: e28. doi: 10.4081/ijas.2010.e28

54. Schneider, M. del P., Dürr J.W., Cue R.I. and Monardes, H.G. 2003. Impact of type traits on functional herd life of Quebec holsteins assessed by survival analysis. J. Dairy Sci., 86: 4083-4089.

55. Sewalem, A., Kistemaker, G.J., Miglior, F. and Van Doormaal, B.J. 2004. Analysis of the relationship between type traits and functional survival in Canadian Holsteins using a Weibull proportional hazards model. J. Dairy Sci., 87: 3938-3946.

56. Zavadilová, L., Němcová E. and Štípková, M. 2011. Effect of type traits on functional longevity of Czech Holstein cows estimated from a Cox proportional hazards model. Journal of Dairy Science, 8: 4090-4099.

57. Zavadilová, L., Němcová, E., Štípková M. and Bouška, J. 2009. Relationships between longevity and conformation traits in Czech Fleckvieh cows. Czech J. Anim. Sci., 54(9): 387-394.

58. Zavadilová, L. and Štípková, M. 2012. Genetic correlations between longevity and conformation traits in the Czech Holstein population. Czech J. Anim. Sci., 57(3): 125-136.

Khmelnychyi Leontii Mykhailovych, Doctor of Agricultural Sciences, Professor

Karpenko Bogdan Mykolaiovych, graduate student

Sumy National Agrarian University (Sumy, Ukraine)

Lifetime of dairy cows depending on the assessment of the udder linear traits

The results of research on the dependence of cows lifetime of Ukrainian Black-and-White dairy (UBWD) and Holstein (H) breeds from the level of linear traits assessment that characterize the morphological udder qualities in the general system of linear classification of conformation type were presented. The experiments were conducted in the herd of the PE "Burynske" Pidlisnivskyi branch of Sumy region. According to the results of linear classification of descriptive traits of conformation type, which characterize the morphological udder qualities of cows firstborn of experimental breeds in the herd: fore udder parts attachment, height of rear udder parts attachment, central ligament, udder depth, a certain correlative variability was determined between the level of assessment of these traits and the lifetime of animals. The highly reliable difference between cows, assessed on the basis of fore udder parts attachment at one and nine score, was quite significant and amounted to 841 (UBWD; $P<0.001)$ and $810(H ; P<0.001)$ days. Interbreed comparison of cow's lifespan, depending on the estimate level, testified in favor of Holstein cows with variability in the range of 43-159 days with an insignificant difference. The difference between the lowest and highest scores for trait - height of the rear udder attachment in cows of experimental breeds was 740 (UBWD; $P<0,001)$ and $810(H ; P<0,001)$ days. Animals with the assessment for the central ligament development of the udder below 1-3 score living, according to the evaluated breeds, from 2089 to 2401 (UBWD) and from 2154 to 2468 (H) days. Cows with estimate in nine score of both breeds have the highest lifespan - 2663 days (UBWD), yielding to cows with the lowest score at 754 days $(P<0.001)$ and 2803 days $(H)$ with a significant increase by 649 days $(P<0.001)$. The difference between the average life expectancy of cows with the assessment in nine score and estimation of one score for udder depth was 739 days for Ukrainian Black-and-White dairy cows $(P<0.001)$ and 832 days for Holstein cows $(P<0.001)$. The lifespan of cows of both breeds in the herd, depending on the assessment of the front teats position was characterized by insignificant curvilinear variability. That is, the longest used in the herd cows of both breeds with an average estimate 7 score. In further, deviations were observed with an insignificant difference in the direction of reducing lifetime estimated in 8-9 and 65 scores with an advantage of Holstein cows. A significant reduction in lifespan of cows began with estimates for this trait from four to one score. An assessment of the correlative variability for the length of fore teats with the cows lifetime in the controlled breeds indicated that the cows had a longer functional life with an average estimate of five score, equal to their length at the level of $5 \mathrm{~cm}$.

Key words: Ukrainian Black-and-White dairy breed, Holstein, linear type traits, lifetime.

Дата надходження до редакції: 15.04.2021 р. 